\title{
高感度磁気センシング技術の開発とその応用
}

\author{
正 員 脇若 弘之*
}

\section{Development of High Sensitive Magnetic Sensing Technologies and their Applications}

Hiroyuki Wakiwaka*, Member

\begin{abstract}
Sensing technologies using magnetic sensors and magnetism are kinds of an important technology to support today's information society. This paper describes a review of recent magnetic sensors with high sensitivity first. The content of the second description is a feature with the sensing technologies using magnetic sensors and magnetism. Finally, it introduces applied field and the application example of the sensing technologies using magnetic sensors and magnetism.
\end{abstract}

キーワード : 磁気センサ, 高感度, センシング技術

Keywords : magnetic sensor, high sensitivity, sensing technology

\section{1. まえがき}

筆者は, 電気学会磁気利用センシングシステム調査専門 委員会において高感度磁気センサおよびセンシング技術に ついて調査研究してきた。磁気センサは, 磁界を測定対象 とするセンサと磁性体などの磁気特性変化を利用して, 変 位, 位置, 速度, 力, トルクなどの力学量または何らかの 情報にもとづく電気信号を出力するセンサに大別すること ができる。前者は, 磁界センサとも呼ばれ, 狭い意味での 磁気センサであり，平成 14 年度には約 1000 億円の生産実 績が報告されている。磁気センサは多種多様な動作原理に 基づくものがあり，日常生活の身近なところから科学技術 の最先端分野まで各種のセンサが使用され，今日の情報化 社会を支えるキーデバイスの一つである ${ }^{(1)}$ 。

磁界・磁気現象を電気信号に変換する磁気センサの原型 は, 磁界と電気の関係が研究され始めた 1830 年代に遡るこ とができ，磁気センサの歴史は古いと言えるが，年々新し い現象や効果が発見され, 磁気センサに適した材料開発が 進み, ニーズに対応する新しい磁気センサが開発されてい る。中でも最近の薄膜作成技術の進展により作成できるよ うになった人工格子における巨大磁気抵抗効果に基づくデ バイスが注目されている(2)。

磁界センサは, ブラシレス DC モータの磁極検知や電流セ ンサ，ハードディスクに磁気記録された情報を読み取るた めのセンサ，磁気カードや切符を読み取るためのセンサ

\footnotetext{
* 信州大学工学部

干 380-8553 長野市若里 4-17-1

Faculty of Engineering, Shinshu University

4-17-1, Wakasato, Nagano 380-8553
}

などに使用されている。また，磁気コンパスに変わる方位 センサとして小形電子コンパスが開発され, 携帯電話に組 み込まれている。

本稿では, 高感度磁気センシング技術として主な高感度 磁気センサの種類について概略を解説し, それらの最近の 開発例を示した。さらに, 高感度センシング技術の応用例 について具体例を紹介する。

\section{2. 高感度磁気センシング技術}

〈2・1〉磁気センサの種類図 1 に自然環境と代表的 磁気センサの適用範囲との対応を示した。計測対象となる 磁界の範囲は, $\mathrm{fT}$ オーダから数 $\mathrm{T}$ の範囲であり, きわめて 広い範囲にわたっている。いわゆる地磁気は $30 \mu \mathrm{T}$ 程度であ り, モータや発電機などの電気機械は $2 \mathrm{~T}$ 以下の磁束密度で 使用されている。生体磁気は, 人間の心臓の拍動によって 生じる磁界, すなわち心磁界は数 $\mathrm{nT}$ 程度であり, 脳内の神 経活動による磁界, 脳磁界は pT のオーダである。磁界セン

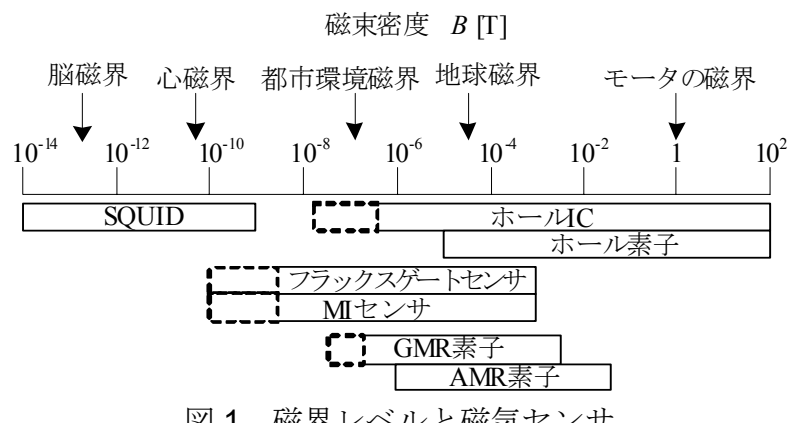

四 1 磁界レベルと磁気センサ

Fig. 1. Magnetic field level and magnetic sensor. 
サとしては電磁誘導の法則によるサーチコイルを始めとし て各種の物理法則, 効果が利用されている。

中でも磁界センサの代表格とも言えるホール素子は，そ れだけで, 年間 20 億個近くが生産されている。また, 磁気 記録の分野においてスピンバルブ GMR 素子が年間数億個 磁気記録読み取りヘッドに使用されている。磁気センサと しては, これらの他に, 磁気光学効果を利用した磁界セン サやプロトン磁力計などがある。

さまざまな物理量に基づく磁界変化や磁気特性変化から その原因となる物理量を検知する磁気利用センシング技術 は，高感度な磁気センサの開発と信号処理によってますま 寸適用範囲が広がっている。磁気利用センシングには, そ れぞれに合った磁界センサが使われるが，磁界センサ同士 で競い合い，取捨選択される。例えば，GPS を搭載した携 帯電話に電子化された方位センサ（コンパス）が組み込ま れると, 位置情報と向きを組み合わせて常に画面の上と向 いている方向が一致する地図のヘッディングが可能にな り, パーソナルナビゲータの実用性が高まるため, 地磁気 を利用した方位センサ組み込みが望まれる。携帯電話に組 み込み可能な小形低消費電力の方位センサとして, ホール 素子, AMR 素子, GMR 素子, フラックスゲートセンサ, MI センサなどを使用した電子コンパスが各社から製作さ れ, いくつかの方式の方位センサが携帯電話に搭載され始 めている。

磁気センサの動作原理となる新しい物理現象・原理は, 現在に至るまで絶え間なく発見され，それらに基づいた磁 気センサ，センシング技術が年々登場している状況である。

〈2·2〉 ホール素子 ホール素子は, 磁界計測用プロ ーブとして使われてきたが，近年，ブラシレス DCモータや 電流センサなどへの組み込夕使用, VTR など情報機器用精 密モータの回転検出や自動販売機の紙幣認識など家電・工 業の分野で年間 20 億個近くが使用されている代表的な磁気 センサである。

ホール効果（Hall effect）は, 1879 年, H.Hallによって発 見された。これは, 直方体の素子に電流を流し, その電流 と垂直方向に磁界を加えると, 電流と磁界の方向にそれぞ れ垂直方向に電圧が発生する現象である。素子に発生する ホール電圧は, 定電流駆動, 定電圧駆動に対応して以下の 式で表すことができる。

$$
\begin{aligned}
V_{H} & =K_{H} \cdot I_{c} \cdot \frac{B}{d} \\
& =\mu_{H} \cdot \frac{w}{l} \cdot V_{i n} \cdot B
\end{aligned}
$$

ここで, $K_{H}$ はホール係数 $[\mathrm{Vm} / \mathrm{AT}], I_{c}$ は制御電流[A], $\mu_{H}$ は電子移動度， $V_{i n}$ は印加電圧 $[\mathrm{V}]$ である。

ホール素子は, 当初, 移動度の大きな InSb のバルクの単 結晶を研磨して使用されていたが，1970 年代に半導体のウ エハープロセスを適用し, 多結晶薄膜化することによって 工業的に安定な素子の生産が可能になった。

ホール素子の材料として, シリコン $(\mathrm{Si})$, ゲルマニウム
(Ge), ガリウム・ヒ素 $(\mathrm{GaAs})$, インジウム・ヒ素（InAs）， インジウム・アンチモン $(\mathrm{InSb})$ 等の半導体が使用される。 この中で, InSb は高感度であるが, ホール係数は温度係数 が大きい。GaAs は, 感度が低いが温度係数が小さい等の特 徵がある。Si は低感度であるが, 同じウエハーに回路を集 積し, ホール IC を作成することができる。図 2 は, 電子移 動度の温度係数を小さくするために, Si をドープした InAs 薄膜のホール素子のチップ写真であり， -40 から $+150^{\circ} \mathrm{C} ま$ での広い温度範囲で使用することができる(3)。

〈2·3〉 MI センサＭI センサは, アモルファス強磁性 ワイヤや薄膜を高周波で励振したとき, 表皮深さが外部磁 界によって変化し, そのためにインピーダンスが変化する ことを利用したセンサであり，1993 年に，毛利氏が発表し た現象を利用している。

使用されているアモルファスワイヤは直径 $100 \mu \mathrm{m}$ 以下, 長さ $2 \mathrm{~mm}$ 程度のサイズである。これは, 高感度であり, 方 位センサや情報分野への応用が進んでいる。MIセンサは, フラックスゲートセンサに比べて磁界検出感度は同程度, ヘッド寸法は約 1/30（1２ $\mathrm{mm}$ ), 応答速度は 1000 倍（約

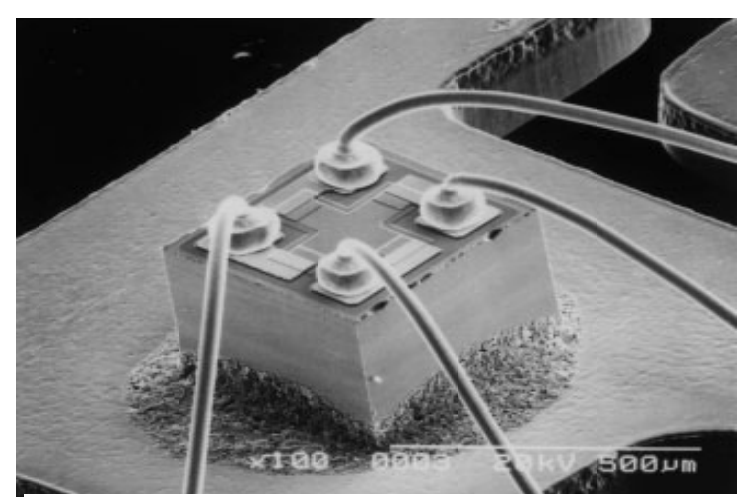

図 $2 \mathrm{Si}$ ドープ InSb ホール素子チップ(旭化成)

Fig. 2. Si dope Hall element chip(Asahi Kasei).

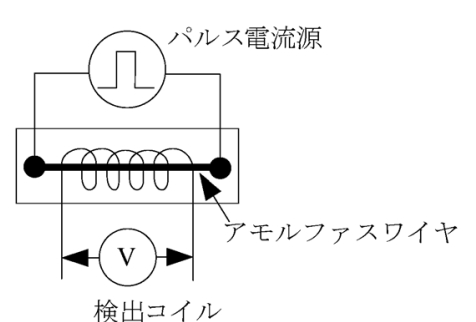

(a) MI センサヘッドの構成

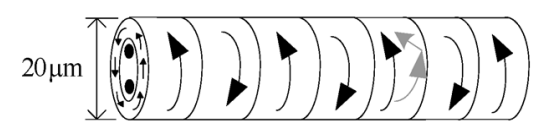

(b) アモルファスワイヤの磁区構造

図 3 MI センサの基本原理

Fig. 3. Basic principle of MI sensor. 
$1 \mathrm{MHz}$ ) である。

MI センサとフラックスゲートセンサの動作原理は異なる が，動作としては高周波で励振することによって磁界に比 例した高調波出力電圧を得るものである。同様な動作のセ ンサとして，例えば，薄膜技術による高周波キャリア形磁 界センサがあげられる。これは, $\mathrm{GHz}$ 帯において pT オーダ の交流磁界感度を有し, 電磁ノイズ等の測定に適したセン サであり，プリント配線基板近傍の EMC 測定などに使用さ れている。

〈2・4〉磁気抵抗素子抵抗值が磁界によって変化す る素子として, 半導体形, AMR, GMRなどがあるが, これ らはそれぞれ動作原理が異なっている。半導体形磁気抵抗 素子は, 高感度なため, 磁気カードの読み取りや紙幣の判 別にも使用されているが温度特性等の点で用途が限られて いる。AMR 素子は，エンコーダや VTR の位置検出に使用 されている。GMR 素子は, 主に磁気記録の分野で読み取り ヘッドとして年間数億個が使用され, 磁気記録密度の向上 に重要な役割を果たしている。

\section{$\langle 2 \cdot 4 \cdot 1\rangle$ 異方性磁気抵抗 (AMR) 形素子 強磁性体} 中の抵抗は, 電流方向と磁化方向の角度によって異方性を 生じるため AMR 効果 (Anisotropic Magnetoresistive Effect : 磁気異方性効果）素子と呼ばれる。AMR 効果は W.Thomson によって 1857 年に発見されたが，バルク材や半導体では小 さく，実用的ではなかった。1970 年代に入り，薄膜作成技 術により作成された素子の登場により，実用化が広まった。 その抵抗率変化は次式で表される。

$$
\rho=\rho_{0}+\Delta \rho \cos ^{2} \theta
$$

ここで， $\theta$ は薄膜の磁化 $M$ と測定電流の間の角である。 AMR 効果による磁気抵抗素子は, $5 \mathrm{kA} / \mathrm{m}$ で 3\%程度の抵抗 変化があり, 磁界変化に対する感度は $0.8 \% /(\mathrm{kA} / \mathrm{m})$ 程度で ある。 AMR 素子は， FeNi パーマロイや FeCo 合金などの金 属薄膜で, 温度係数が小さく安定である。1970 年代後半に 登場した金属薄膜により実用レベルの磁気抵抗素子が量産 化さら, 磁気エンコーダや磁気ヘッドへ利用された。

〈2.4-2〉 巨大磁気抵抗効果 (GMR) 素子 1988 年 に巨大磁気抵抗効果 (Giant Magnetoresistive : GMR) が発見 された。これは，スピンと磁気モーメントの交換相互作用 によって生じる抵抗が磁界の大きさと向きとによって大き く変化する現象であり, 磁気記録の面密度向上に欠かせな い物となっている。当初開発された GMR 素子は, 数 $\mathrm{nm}$ 厚 さの磁性層と非磁性層が交互に積層され, 層間の相互作用 により伝導電子が散乱されることにより抵抗值が変化する 多層形 GMR 素子であり, 抵抗変化率 $\Delta R / R$ は数十\%以上の ものもある。現在 HDD 読み取りヘッドに利用されている GMR 素子はスピンバルブ形 (SV) であり，より一層高密度 化するため, 絶縁層におけるトンネル効果を利用した TMR 素子や膜厚方向の抵抗変化を利用する CPP 形 GMR 素子が 精力的に研究開発されている。最近では, 図 4 に示すよう に，300Gbpsi（ギガビット/平方インチ）の読み取りのでき

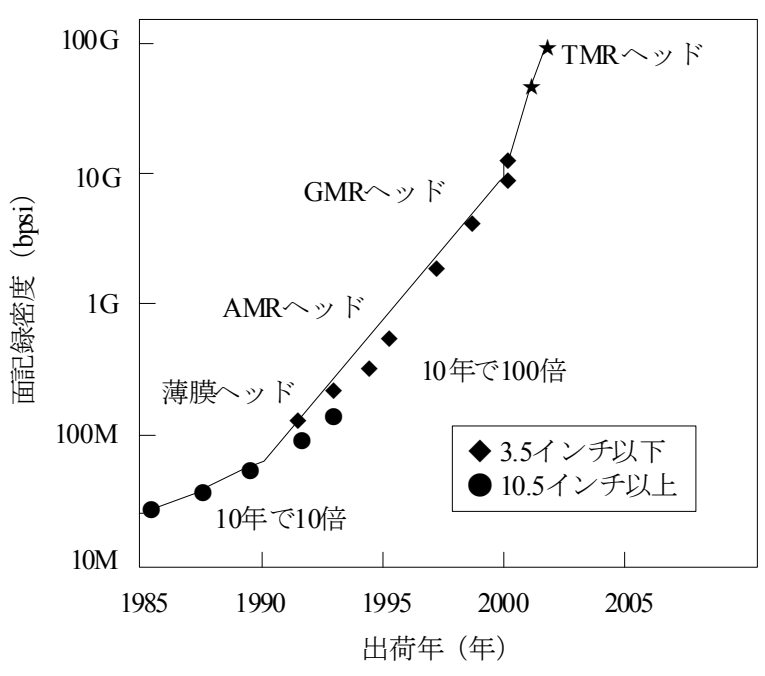

図 4 磁気記録密度変遷の歴史

Fig. 4. History of magnetic recording density tra-nsition.

る TMR ヘッドも発表されている(4)。

〈2.5〉 超電導量子干渉素子（SQUID） 生体磁気の 様にきわめて微弱な磁界測定には, 超電導量子干渉素子 (SQUID: superconducting quantum interference device) が利用 されている。これは, リング状超電導体の一部をジョセフ ソン接合させたもので, リングを通過する磁束量子 $\left(2 \times 10^{-15} \mathrm{~Wb}\right)$ の検出が可能で, きわめて高感度な磁界センサ として利用されている。ジョセフソン接合は薄い絶縁膜を 介して超電導体を接合したもので, ジョセフソン接合を流 れるトンネル電流は以下の式で表される。

$$
I=I_{0} \frac{\sin k B}{k B} \quad[\mathrm{~A}]
$$

ここで， $I_{0}$ は無磁界中の電流， $B$ は接合面に垂直な磁束密 度, $k$ は定数。すなわち, 接合が一つの時の電流は, 接合に 加わる磁束密度の周期関数になる。

SQUID には,一つまたは二つのジョセフソン接合を持つ dc-SQUID と rf-SQUID がある。dc-SQUID の分解能は抵抗の 熱雑音によって決定される。SQUID は $1 \times 10^{-10}-1 \times 10^{-12} \mathrm{~T}$ の微弱磁界を検出できるため, 心臓内の流れる血液の血流 変化を心電図と同じように記録することができる。SQUID は, 実用化されている磁気センサの中では最高の感度を持 っているため, 心臓の鼓動による磁界検出ばかりでなく脳 細胞の活動による脳磁界の検出にも用いられている。

ジョセフソン効果とは, 2 つ超電導体が薄い絶縁膜で隔 てられているとき, クーパー対のトンネル効果によって絶 縁膜を通して流れる超電導電流に関連した効果であり，こ のような素子をジョセフソン接合という。直流ジョセフソ ン効果と交流ジョセフソン効果がある。

SQUID は, 現在室温で使用されているフラックスゲート センサの 1,000～5,000 倍高感度であるが，SQUID 本体の最 大の感度はシステム雑音によって決定される。金属系超電 導体 SQUID の磁気雑音（SQUID のシステム雑音）は, 0.5 
$\sim 5 \times 10^{-6} \Phi_{0} / \mathrm{Hz}$, 高温超電導体 SQUID で $10^{-5} \sim 10^{-4} \Phi_{0} / \mathrm{Hz}$ である。ただし， $\Phi_{0}=2 \times 10^{-15} \mathrm{~Wb}$ である。

\section{3. 高感度磁気センシング技術の応用例}

高感度磁気センサは，実用機器に不可欠となっている。 ここではそれらの中から一部を紹介する。

〈3.1〉自動車用途への応用最近の自動車は, エン ジン制御, 車体制御, 車両制御系すべてにおいて電子制御 系が構成され，性能・安全性・快適性が飛躍的に向上され ている。これらの制御のために, 数多くのセンサが搭載さ れている。磁気センサは, 一般に堅牢で過酷な環境にも使 用でき，信頼性が高いため，図 5 に示したように数多く使 用されている(5)(6)。

$\langle 3 \cdot 2\rangle$ 生体磁気計測分野への応用病気の診断や脳 機能の解明のために生体から発生する磁界測定は, 電極が 不要など無侵襲であり, 心電図や脳波測定とに比べて, 生 体に対する影響が少ない。また多チャンネルの測定によっ て活動部位の推定ができるなどの特徵がある。しかし，生 体から発生する磁界は, きわめて微弱なため高感度な磁気 センサが必要とされ, SQUID 磁束計の登場によって測定が 実用的になった。しかし, 図 1 に示したように, 生体から の磁界は環境磁界に比べ非常に弱いので，測定には，高性 能なシールドルームが必要とされるが SQUID プローブコイ ルを工夫して環境磁界を打ち消寸工夫も行われている。

生体磁気計測の分野で最近活発に研究が進められている 課題として, 直径が $10 \mathrm{~nm}$ から数百 $\mathrm{nm}$ 程度の磁気微粒子検 出がある。これらの磁性微粒子は, DNA 検出診断や免疫検 査においてキャリヤーとして利用されるもので, それらの 生体や液体中における密度や通過状況を把握するために磁 気センサが利用される。ここに使用できる磁気センサは, 高感度であると同時に微小感磁領域のセンサであること, すなわち空間分解能に優れていることも重要である。高感度 であり，感磁領域を数 $\mu \mathrm{m}$ 角にしたセンサとして, SV-GMR, プレーナ形ホール素子などが開発研究されている(7)(8)。

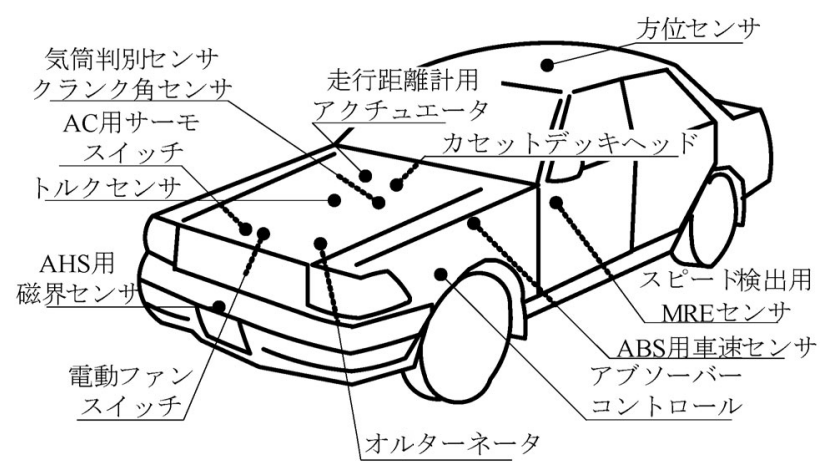

図 5 自動車用磁気センサ

Fig. 5. Magnetic sensors equipped automobile.

\section{4. あとがき}

磁気センサの歴史は古く, 電磁誘導現象が発見されて以 来, 今日にいたるまで, 磁気センサに関係の深い重要な物 理・効果が次々に発見され活用されている。磁気センサは 高信頼性, 耐環境性, 低コストなどに優れ, 極めて多くの 用途に使用されているが，さらに新しいニーズに応える 様々な磁気センサが登場し, 高感度化, 小形化, 高機能化 および空間分解能の高密度化が進められている。

本稿で解説・紹介したように, 測定可能な磁界の範囲も fT オーダから数 $\mathrm{T}$ まで実に幅広いと言えるが, 年々, 新た なセンサが開発されている。高感度磁気センサは, 空間分 解能の微細化と応答周波数の拡大に向かってマイクロ化と 集積化が展開されている。例えば，スピンエレクトロニク ス分野の技術による巨大磁気抵抗効果による磁気顕微鏡 や, 高温超電導による SQUID の生体磁気一の応用, 非破壊 検査への適用など期待されている分野が多い。

磁気利用センシングシステム調查専門委員会の調査内容 のごく一部を紹介したが，ここで解説できなかった先端的 磁気利用センシング技術調査結果は技術報告書として出版 される予定である。

本稿作成にあたり，多くの方々から最新のデータ・情報 をいただいたことに感謝申し上げる。本稿により, 磁気セ ンサへの興味と関心が今まで以上に持たれれば幸である。

(平成 18 年 3 月 20 日受付)

\section{文献}

(1) P. Ripka, ed. : Magnetic sensors and magnetometers, Artech House (2000)

（2）日本応用磁気学会：「磁気センサ・磁気計測技術の最新動向」, 第 129 回研究会資料 (2003)

(3) 柴崎一郎：「InSb 単結晶薄膜の物性と磁気センサ応用」, 電学論 $\mathrm{E}$, Vol.123, No.3, pp.69-78 (2003)

(4) 猪俣浩一郎：「21 世紀を支える磁気メモリ」, 電気と磁気の新しい交 わり スピンが拓く 21 世紀のエレクトロニクス, p.153, クバプロ (2001)

( 5 ) 西部祐司：「磁気センシングの ITS への応用」, 非破壊検査, Vol.52, No.9, pp.473-478 (2003)

（6）脇若弘之：「自動車に使われている磁気利用センサ」, まぐね, Vol.1, No.1, pp.19-24 (2006)

(7) J. C. Rife, et.al., "Design and performance of GMR sensors for the detection of magnetic microbeads in biosensors", Sensors and Actuators A, 107, 209-218 (2003)

( 8 ) A. Sandhu : "Thin-film semiconductor Hall effect bio- sensors for medical applications”, IEEJ Trans. SM, Vol.125, No.11, pp.444-447 (2005)

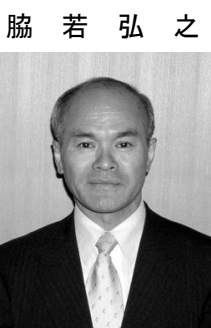

（正員） 1947 年 10 月生まれ。1974 年 3 月信州 大学大学院修了。同年 4 月小野測器入社。1991 年 2 月信州大学工学部助教授。 2002 年 4 月信州 大学工学部教授。磁気センサ, 磁気を利用した 変位, 力, トルクセンシング, 電磁アクチュエ ータ, モータなどの研究に従事。工学博士。電 気学会磁気利用センシングシステム調査専門 委員会委員長。 